\title{
The Ideational, Interpersonal and Textual Meaning in Jokowi Dodo's Inauguration Speech
}

Samsudin, Institute of Social Science and Culture Samawa Rea-Sumbawa

*Corresponding Author : Samsudinsyam18@yahoo.com

Received Date: 10-05-2019 Accepted Date: 28-06=2019 Published Date: 31.-07-2019

Abstrats - Systemic Functional Linguistic offers a model of approach in analyzing discourse concerning to reveal how language is used to negotiated meaning. Research paper, also known as research article presents Jokowi Dodo's Inauguration speech in terms of Ideational, interpersonal and textual meaning. Therefore, this study aimed to explain the realization of Ideational, Interpersonal and Textual Meaning in Inauguration speech. Descriptive qualitative Research design was used in this study with one Jokowi Dodo's text speech taken as the subject of analysis. The findings revealed that the meanings were realized by the president's language choice. Ideational meaning realized in research paper showed that the president presented his future dreams in state of doing through relational process and material process with help of other process types. However, Interpersonal meaning realized in the research paper showed that the research paper was carrying the speech role as giving information. Textual meaning was realized through the use of the speech opening and giving appreciate to participants who attended in Inauguration speech and also hopes to all participants. The realization of the meaning also could give benefit to participant and researcher in having guideline when they are giving speech in public area.

Keyword: Ideational, Interpersonal, Textual Meaning, Jokowi Dodo's Inauguration speech text.

\section{Introduction}

Public speeches are delivered orally, which are often well-prepared in writing and presented on formal occasions. Based on the functions and contents, political speech is a kind of public speech given by authorities with political purposes that tries to influence a certain group of people. This paper uses the Inauguration speech as selected president 2014-2019 after taking oath in front of Parliament members in Jakarta on October 20, 2014.

Functional Grammar grew out of the work of J.F. Firth and was mainly developed by M.A.K. Halliday. It is a theory of language centered on the notion of function. Halliday (2000) proposed that language has three meta-functions, the ideational, the interpersonal and the textual.

Bilal (2012) and Kamilah (2014) attempted to identify three meanings in metafunction in literary works of Thank You M'am and Invictus. Both studies revealed how metafunction 
analysis reveals hidden characteristics and intention of the main role. Furthermore, the studies also proposed benefit of metafunction analysis in EFL learning concerning on how language can be used to achieve communicative goals in different context.

This research aims to answer the question what is the interpersonal and textual meaning of the “ Jokowi Dodo's Inauguration Speech" . This research is also different to the previous research where this research tries to explore the ideational, interpersonal and textual meaning contained in different text.

\section{Reseacrh Methode}

This study was a qualitative study which the data were taken from Jokowi Dodo's Inauguration Speech. After the data collected in observation sheet, the writer continued to analyze the data. There are some steps namely identify, classifying, reducing, interpreting, and inferring.

\section{Result and Discussion}

The ideational function is represented in text by transitivity. It is a basic semantic system, which construes the world of experience into a manageable set of process types. Halliday divides these processes into six types: material process, mental process, relational process, behavioral process, verbal process and existential process.

\section{Overview of Process Types}

\begin{tabular}{|l|l|l|}
\hline Process types & Core meaning & Participant \\
\hline Material & 'doing', 'happening' & Actor, Goal \\
\hline Mental & 'sensing' & Sensor, phenomenon \\
\hline Relational & 'being' & \\
\hline Verbal & 'saying' & Sayer, Reciever, Verbiage \\
\hline Behavioral & 'behaving' & Bahever \\
\hline Existential & 'existing' & Exiten \\
\hline
\end{tabular}

\section{Material process}

Material process is a process of "doing". The process is usually indicated by a verb expressing an action, either concrete or abstract. There are usually two participants in the process: Actor and Goal. Actor is comparable to the Subject and Goal is comparable to the Object and both of them 
are usually realized by noun phrases. When the participants both exist, the clause can be either in active voice or in passive voice.

\section{Material processes of transitivity realized in Jokowi Dodo's Inauguration Speech}

Halliday (1994: 110), states material processes express the notion that some entity physically does something which may be done to some other entity.

Example:

\begin{tabular}{|c|c|c|}
\hline Actor & Process & Goal \\
\hline I, Indonesia, & $\begin{array}{l}\text { Thank, appreciate, want, } \\
\text { keep, contribute, implore, } \\
\text { urge, }\end{array}$ & $\begin{array}{l}\text { The attende of fellow state } \\
\text { leaders and special delegates, on } \\
\text { practicing nation and active } \\
\text { foreign diplomacy, be present } \\
\text { among other independent nations } \\
\text { with dignity and pride, to build } \\
\text { our own civilization, become a } \\
\text { creative nation, a nation that } \\
\text { contributes nobility to the worlds } \\
\text { civilization, ,for the national } \\
\text { interest, in creating a world order } \\
\text { in accordacne with principles of } \\
\text { freedom, eternal peaces, and } \\
\text { social justice. You fellow } \\
\text { countrymen, }\end{array}$ \\
\hline $\begin{array}{l}\text { We, state } \\
\text { institutions, I } \\
\text { and vice } \\
\text { presidesnt, }\end{array}$ & $\begin{array}{l}\text { have just taken, unite, } \\
\text { continue, transform, share, } \\
\text { do, written, work, build, } \\
\text { done, need, protect, improve, } \\
\text { contribute, thanks }\end{array}$ & $\begin{array}{l}\text { our oaths. out heart and hands. } \\
\text { Indonesia into a sovereign } \\
\text { country polically, self-sufficient } \\
\text { economically, and with a strong } \\
\text { character culturally. this heavy } \\
\text { task together with unity and } \\
\text { working together and hard work. }\end{array}$ \\
\hline
\end{tabular}




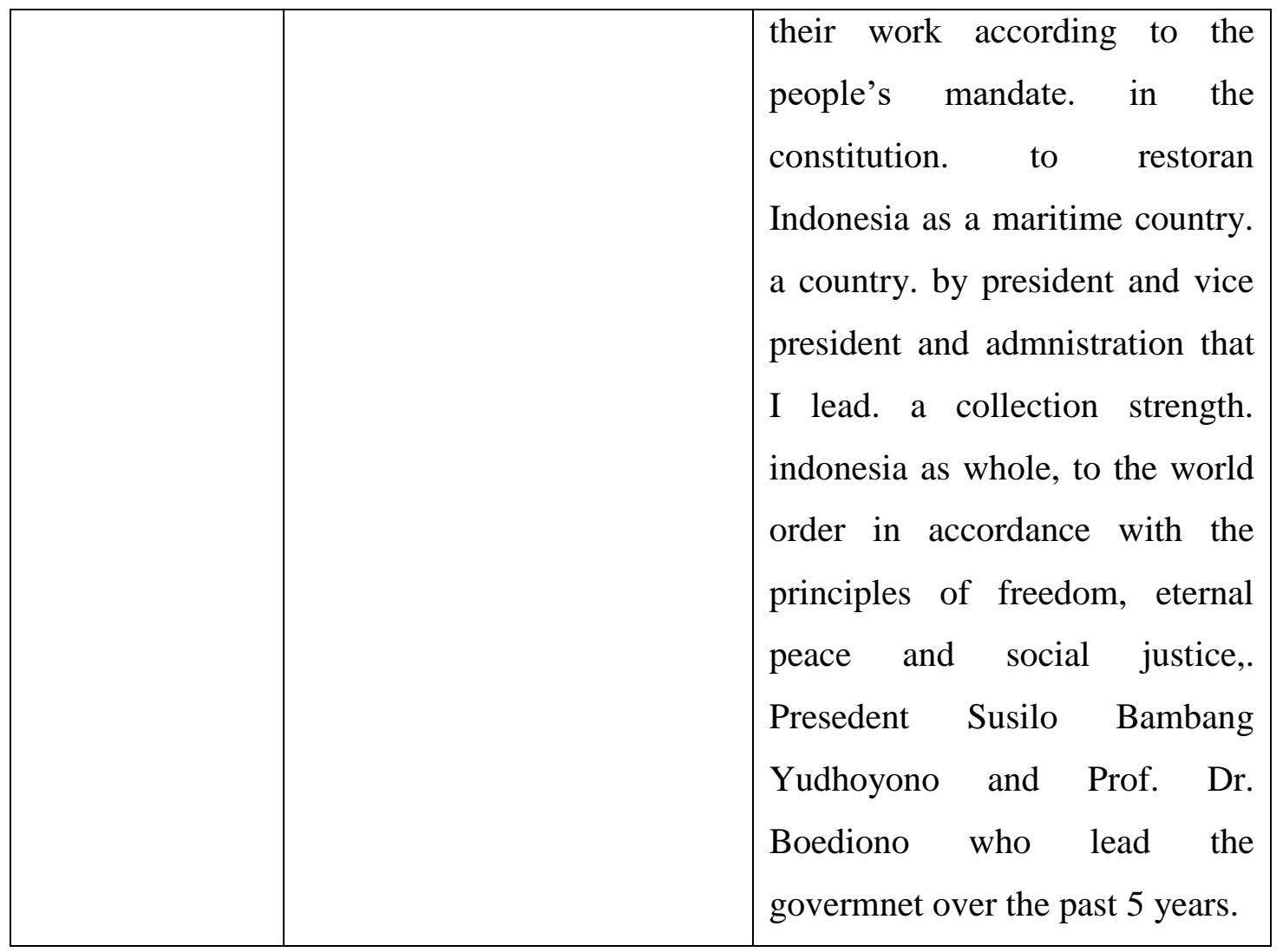

From the table of mental process above, it indicated the speaker used the process of doing something physically, bodily, and materially.

\section{Relational processes realized in Jokowi Dodo's Inauguration Speech}

Relational process is a process of being. It can be divided into two modes: attributive relation and identifying relation. The first means what properties an object possesses or what category it can be put into. And the other means that an entity and another is uniform. It is used widely in describing people and objects.

Example:

\begin{tabular}{|l|l|l|}
\hline \multicolumn{1}{|c|}{ Carrier } & \multicolumn{1}{|c|}{ Attributive: possesive } & \multicolumn{1}{|c|}{ Attribute } \\
\hline $\begin{array}{l}\text { That oath, it, I, gotong } \\
\text { royong, the nation, } \\
\text { this, work, }\end{array}$ & Has, is, am, become, be & $\begin{array}{l}\text { a deep spiritual meaning, time, } \\
\text { a prerequisite, certain, certain }\end{array}$ \\
& & $\begin{array}{l}\text { with hard work and working } \\
\text { togerher,a big nation, a } \\
\end{array}$ \\
& stronger, the historic moment \\
\hline
\end{tabular}




\begin{tabular}{|l|l|l|}
\hline & & $\begin{array}{l}\text { for us all to move together and } \\
\text { to work, to restore everything, } \\
\text { the priority, }\end{array}$ \\
\hline $\begin{array}{l}\text { We, the oceans/the } \\
\text { seas/th bays/and the } \\
\text { straits, the next } 5 \\
\text { years, }\end{array}$ & Become, be, are, have, & $\begin{array}{l}\text { A big nation, truly free without } \\
\text { hard work, the future of our } \\
\text { civilization, far too long turned } \\
\text { our back on the seas/the } \\
\text { oceans/the straits/and the bays, } \\
\text { a momentum to show our } \\
\text { freedom as a nation, }\end{array}$ \\
\hline
\end{tabular}

The word "That oath, it, I, gotong royong, the nation, this, work, we" as carrier, and "Has, is, am, become, be" as attributive (possessive), and "a deep spiritual meaning, time, a prerequisite, certain" as attribute, it indicated the speaker used expressing, possession, equivalence and attributes.

\section{Mental Process Realized in Jokowi Dodo's Inauguration Speech}

Mental process is a process of feeling, thinking and seeing. Actor is not the real subject of doing, but the feeling. It represents inner experience, such as "perception", "reaction" and "cognition". We call the two participants are Senser and phenomenon.

Example:

\begin{tabular}{|l|l|l|}
\hline Senser & Mental & Phenomenon \\
\hline $\begin{array}{l}\text { My administration, every } \\
\text { person, I, }\end{array}$ & Ensure, feels, & $\begin{array}{l}\text { Presence of their } \\
\text { goverment, }\end{array}$ \\
\hline
\end{tabular}

The word "My administration, every person, I" as senser, "Ensure, feels," as mental processes, "Presence of their government" as phenomenon, it indicated the speaker uses process of sensing.

\section{Behavioral process Realized in Jokowi Dodo's Inauguration Speech}

Behavioral process is process of physiological and psychological behavioral, like breathing , dreaming, snoring, smilling, hiccuping, looking, watching, listening, and pandering. There is one 
obligatory participant: the behaver. Like a senser, the Behaver is a conscious being. But the process is one of doing. However, In this text there is no behavioral process contained within it because the writer did not analyze the spoken text so that it is impossible to analyze the behavioral process. In this case the writer only analyzed the written text taken from internet.

\section{Verbal process Realized in Jokowi Dodo's Inauguration Speech}

perception of verbs refers to "seeing", and "feeling". It processes of saying, and symbolically signalling. There are two distinct clauses, the projecting clause encodes a signal source "sayer", signalling "verbal process" and the other "projected clauses. The participants are sayer, target, receiver, and verbiage. Sayer is the signal source, target is the one acted upon verbally, receiver is the one to whom the verbalization is addressed, and verbiage is a name for the verbalization.

\section{Example:}

I implore you fellow countrymen to
remember one thing as said by the first
president of the Republic of Indonesia, Bung
Karno.

The sentence "I implore you fellow countrymen to remember one thing" as receiver, "said" as verbal processes, "the first president of the Republic of Indonesia, Bung Karno" as sayer, it indicated that the speaker used processes of communication.

\section{Existential Process Realized in Jokowi Dodo's Inauguration Speech}

Existential processes are processes represent something exist or happened; it can be said processes about the existence. The processes are expressed by verbs of existing, such as be, exist, arise and it is signalled by "there". The participant of this process called existent. Based on the analysis of result that this text does not contain existential process. 


\section{Interpersonal Meaning}

Hu Zhuanglin (1988) points out: "The interpersonal function embodies all uses of language to express social and personal relations. And Modality and Mood are often used to express the interpersonal function. Mood shows what role the speaker selects in the speech situation and what role he assigns to the addressee. Whereas modality refers to the intermediate ranges between the extreme positive and the extreme negative. It is one of the most important systems in social communication. On the one hand, it can objectively express the speaker ${ }^{\text {re }}$ s judgment toward the topic.

\section{Modality Analysis}

Modality refers to a speakeres attitudes towards or opinion about the truth of a proposition expressed by a sentence. It also extends to their attitude towards the situation or event described by a sentence.

Example:

\begin{tabular}{|l|c|c|c|c|}
\hline $\begin{array}{l}\text { Modal } \\
\text { auxiliary }\end{array}$ & Can (1) & Will (11) & Should & Have to \\
\hline modality & Inclination/futurity & Ability/possibility & Obligation & Obligation \\
\hline Frequently & 1 & 11 & 0 & 0 \\
\hline
\end{tabular}

From tabel above, we can see the frequency of modal that Jokowi Dodo used when he red the oath during his swearing-in ceremony as new Indonesia president in front of Parlement member. There are some modal that Jokowi used, namely, 1 (8,3\%) modal 'can', 3 (37,5\%) modal 'have to and 'need to', $11(92 \%)$ modal 'will', and 1 (8,3\%) modal 'can't'. The using of modality auxiliary indicates that the speaker is sure and able to make Indonesia to be developed country. His conviction can only be achieved through work together and work hard either with his administration or citizen. The using of modality auxiliary also show that all his saying is the future dreams.

\section{Tense Shift}

Tense is the time of a clause. Halliday (1994) points out that primary tense means past, present or future at the moment of speaking; it is the time relative to "now". 


\begin{tabular}{|l|c|c|c|c|c|}
\hline \multirow{2}{*}{ No. } & \multirow{2}{*}{ Total Number } & \multicolumn{2}{c|}{ Present } & \multirow{2}{*}{ Simple Past } & \multirow{2}{*}{ Simple Future } \\
\cline { 3 - 4 } & & Simple & Perfect & & \\
\hline No & 48 & 27 & 3 & 3 & 15 \\
\hline$\%$ & & 56,2 & 6,2 & 6,2 & 31,2 \\
\hline
\end{tabular}

From tabel above, we can see that the most frequently of tense is present in which present $(56,2 \%)$, perfect $(6,2 \%)$, simpel past $(6,2 \%)$, and the last is simple future $(31,2 \%)$. In this case the speaker used simple present and future much more to indicate that the speaker are saying the present moment and future dream. Because every people who are given the new position must give speech current condition and what have to do in the future. Thus, based on the such explanation Jokowi Dodo, the new president, used simple present and future much more. However, he did not ignore the old condition. In this case, he certainly used simple past to describe the condition happened in past time. To be a best leader, the new president mush use the past condition as reference to design the gold planning to do in future.

\section{Personal Pronouns}

\begin{tabular}{|c|l|c|}
\hline \multicolumn{2}{|c|}{ Personal Pronoun } & Frequency \\
\hline \multirow{2}{*}{ First Person } & I (me) & 10 \\
\cline { 2 - 3 } Second Person & We (us) & 17 \\
\hline Third Person & You (you) & 3 \\
\hline & He (him) & 0 \\
\hline & She (her) & 0 \\
\hline & It (it) & 2 \\
\hline & They (them) & 0 \\
\hline Possessive Pronoun & 0 \\
\hline My (mine) & 3 \\
\hline Our (ours) & 0 \\
\hline Your (yours) & 0 \\
\hline His (his) & 0 \\
\hline Her (hers) & 1 \\
\hline Its (its) & 0 \\
\hline \multicolumn{2}{|c|}{ Their (theirs) } \\
\hline \multicolumn{2}{|c|}{}
\end{tabular}

As we all know, personal pronouns have a variety of functions in political speech, which can be interpreted from the aspect of social and political roles. They can achieve different interactive 
effects and reflect the speaker's perception of the relationship between the listener and himself.

For table above, we can notice that "we" is the most frequently used personal pronoun, together with "I". "We" can be used to refer to the group excluding the listener or the group including the listener. For example, "we" in sentence 4 and 5 refers to all Indonesian Citizen to work together because based on Jokowi Dodo's explanation that the heavy task can not be done by the single president, but it can be done by work together. To get the truly freedom the selected president, Jokowi Dodo, invites all citizen to work hard.

Then, "we" in sentence 9, 11, 12, 14 emphasize that Indonesia is one of the maritime country with the big sea. Using the first pronoun "we" is also to shorten the distance between the speaker and the audience, regardless of their disparity in age, social status and professions etc. it may include both the speaker and the listener into the same arena, and thus make the audience feel close to the speaker and his points.

Meanwhile, the first pronoun "I" is stated in sentence 4, 7, 8, 17 shows that he believes if all people work together and work hard all problems can be solved and Indonesia will achieve the truly freedom. In last statement the selected president, Jokowi Dodo, thanks to the old President Susilo Bambang Yudhoyon and vice president Doctor Boediono who led the government over the past 5 years.

\section{Mood Analysis}

When we interact with people, we use language clearly to convey the unlimited purposes: we may want to order, apologize, confirm, invite, reject, describe and so on. According to Halliday, most of the fundamental purposes in any exchange are giving (and taking) or demanding (and being given) a commodity of some kind (Halliday, 2000). Halliday (2000) classified two kinds of commodity, which he termed as "information" and "goods-service" and then four speech roles can be identified in Table 1 .

\begin{tabular}{|c|c|c|}
\hline Role Commodity & Good-servis & Information \\
\hline Giving & Offer & Statement \\
\hline Demanding & Command & Question \\
\hline
\end{tabular}


Generally speaking, statements are most naturally expressed by declarative clauses, questions by interrogative clauses and commands by imperative. There also exist exceptions in certain context. For example, some interrogative sentences can also be used to give command with different intonation. In Functional Grammar, the subject and finite make up the mood and the subject-finite positioning in a clause realizes different speech functions, which plays a vital role in carrying out the interpersonal meaning of the clause as exchange and serves a reflection of social role and identity (Eggins \& Slade, 1997).

In Jokowi Dodo's Speech, all of clause adopt declarative mood. There are some considerations why he choses to use declarative mood. First of all, he is the information-giver and he needs to state out his opinions explicitly and express his ideas clearly. As the speech was given after taking oath in front of the parliament members in Jakarta on October 20, 2014. He stated that to get the truly freedom the citizen mush work together and work hard. Jokowi Dodo also used the terms of "Gotong Royong" or work together repeatedly to emphasize that work hard is very important to build a developing country to be developed country because he believes that the president itself can not do alone without other people. He also cites the Slogan "Jalesveva Jayamahe" (in the sea we will triumph) as encouragement to all citizen. Secondly, from the declarative mood, the relation between Jokowi Dodo and the listeners is marked and his authority, status and administration are well established. Declarative sentences not only function as describing, explaining, confirming, but also as advising, suggesting and encouraging. As a president, he has the authority to make comments and analysis of current issues.

\section{Textual Analysis}

The textual meaning refers to the fact that language has mechanisms to make any stretch of spoken or written discourse into a coherent and unified text and make a living passage different from a random list of sentences.

\section{Salutation}

2. The expression of gratitude and honor.

3. Hopes to be a prosperous and peaceful and creative notion in the future

4. Resort to God for helping and blessing. 


\section{Conclusion}

From the research findings and discussion, the researcher concluded that the Jokowi Dodo's position himself as the information giver. He introduced to the reader the relationship between the president role, administration and citizen. The data analysis showed the president maintains the consistency on the speech related to the topic of their research. Therefore, the conclusion of pedagogical implication showing the benefit of meanings realization to the researchers are the language choices and configuration can help the researchers in making research paper. By realizing the three strands of meanings, the other researchers are given guide on how they should organize their language choice properly to create meaning and achieve communicative purpose of the research paper.

\section{References:}

Bilal, H. (2012). Analysis of thank you m'am: Halliday's metafunctions. Academic Research International, 2(1), 726-732.

Halliday, M. A. K.( 1979). Linguistic function and literary style: an inquiry into the language of William Goldinge"s The Inheritors. In Linguistic Studies of Text and Discourse. ed. Jonathan J.Webster. 88-125. Peking: Peking University Press.

Kamilah, F. (2014). Analysis of Invictus: Halliday's metafunctions. Bandung: Indonesia University of Education

http://www.rappler.com/world/regions/asia-pacific/indonesia/72529-text-jokowi inauguration-speech 